\title{
Tacit Knowledge for the Development of Organizations
}

\section{Haradhan Kumar Mohajan}

Assistant Professor, Faculty of Business Studies, Premier University, Chittagong, BANGLADESH

*Corresponding Contact:

Email: haradhan1971@gmail.com

\begin{abstract}
Knowledge is mainly divided into two types: tacit and explicit. The purpose of this study is to examine the concept of tacit knowledge and the application of it for the development of organizations. It is evident that tacit knowledge has a strong connection with the research area of knowledge management. The present global economy is tacit knowledge based for the sustainable development. Since it is very complex in its nature, therefore acquire and extract of tacit knowledge is not a very easy task. It is unwritten, unspoken and hidden vast storehouse of knowledge of a person. It stresses on the success and well-being of humankind. It is obtained as a result of the direct interaction between individuals and their environments. The paper analyzes the importance of tacit knowledge for the sustaining of the long-term capabilities and performance in organizations. An attempt has been taken here to discuss sharing of tacit knowledge in organizations. This paper also tries to explore the properties of tacit knowledge in some detailed.
\end{abstract}

Keywords: Explicit and tacit knowledge, knowledge management, knowledge sharing, knowledge transfer

4/15/2017

Source of Support: Nil, No Conflict of Interest: Declared

This article is is licensed under a Creative Commons Attribution-NonCommercial 4.0 International License.

Attribution-NonCommercial (CC BY-NC) license lets others remix, tweak, and build upon work non-commercially, and

although the new works must also acknowledge \& be non-commercial.

\section{INTRODUCTION}

In the $21^{\text {st }}$ century knowledge becomes the most important resource and vital part for organizations to sustain their competitive advantages. For this it is required to leverage knowledge resources to develop strategic plans for economics and business (Suppiah and Sandhu 2010). Knowledge is widely considered as the most important organizational resource for the long-term sustainable competitive advantage and success of any organization (Nonaka and Takeuchi 1995). Knowledge is a changing method which interacts among experience, skills, facts, relations, values, and thinking (Mládková 2012). Ikujiro Nonaka and Hirotaka Takeuchi demanded that knowledge is initiated from interaction among employees in organizations (Nonaka and Takeuchi 1995).

In organizations, knowledge is divided into two types: explicit and tacit knowledge (Nonaka 1991). Data and information encoded, stored and disseminated are known as content component of the explicit knowledge (Mahmood et al. 2011). Explicit knowledge is 
easily coded, transferred and shared within an organization (Nonaka 1994). Tacit knowledge is highly personal, context-specific, and is difficult to formalize and communicate or transfer from one person to another by the process of writing or verbal expression and is not captured by language or mathematics and also difficult to reduce to writing and is made up of mental models, values, beliefs, perceptions, insights and assumptions (Nonaka 1991, Polanyi 1966, Davenport and Prusak 2000, Nonaka and Nishiguchi 2001). Examples of tacit knowledge are, speaking our own language, manage to ride a bicycle, cook dishes without seeing a recipe, etc. (Polanyi 1966).

Scholars have stressed on the importance of tacit knowledge to the organizations and they observed that greater efforts must be taken to influence on its huge prospective (Beesley and Cooper 2008). In the knowledge management (KM) domain tacit knowledge is used in human resource management, organizational learning, media studies, social psychology and economics (Takeuchi and Nonaka 2004).

\section{TACIT KNOWLEDGE}

Tacit knowledge is difficult to write down, visualize or transfer from one person to another (Magnier-Watanabe et al. 2011). It plays an important role in the knowledgeoriented research in management (Phelps et al. 2012). It is connected with terms such as skills, know-how, know-why, working knowledge, high level of expertise (Crowley 2001).

The term 'tacit knowledge' was first introduced into philosophy by the Hungarian philosopher; physician and chemist Michael Polanyi (1891-1976) in 1958 in his magnum work Personal Knowledge (Polanyi 1958). He famously summarizes the idea of tacit knowledge in his book The Tacit Dimension with the assertion that "We can know more than we can tell" (Polanyi 1966).

\section{Properties of Tacit KnOWledge}

Properties of tacit knowledge can be written as follows (Haldin-Herrgard 2000, McAdam et al. 2007, Pavlicek 2009):

- It resides in human minds and also in relations.

- It is acquired by sharing experiences, observation and imitation.

- It is difficult to learn: learnt through personal experience, practice, apprenticeship, observation, imitation, and reflection.

- It is rarely documented, highly individual, personal and hard to formalize.

- It is unstructured, difficult to see, codify, estimate, investigate, formalize, write down, capture and communicate accurately.

- It is less familiar, unconventional form of knowledge.

- It is rooted in action, procedures, commitment, values and emotions, etc.

- It is learnt through experiences, skills, observation, intuitive feeling, mental modes, beliefs, and values.

- It is experience based (knowledge-inaction).

- It is mostly unconscious and invisible knowledge (both known and unknown to the holder).

- It is non-communicable in a language.

- It is transferred through conversation, storytelling, discussions, analogies, and demonstrations.

- It is subjective, know-how, practical, job specific, experience-based, context-specific, here and now, and expert's knowledge. 


\section{TACIT KNOWLEDGE SHARING}

Tacit knowledge is more difficult to share rather than explicit knowledge, because explicit knowledge is theory-based and transmitted in formal, systematic language (Nonaka 1994). Nonaka and Konno (1998) stated that converting tacit knowledge to explicit knowledge using a process of externalization before sharing can take place. On the other hand, Polanyi (1966) suggest that to be able to share tacit knowledge the possessor of it must first become conscious of the knowledge he possesses and then finds a way to express the knowledge. Only after this occurs can a sharing of knowledge take place.

Knowledge sharing is the process by which knowledge held by an individual is converted into a form that can be understood, absorbed and used by other individuals through channels or networks between knowledge providers and seekers (Hong et al. 2011).

As the tacit knowledge is always stored in peoples' brains, sharing of tacit knowledge is difficult, complex, time consuming and one of the biggest challenges of KM (Hislop 2009, Mládková 2012).

About two-thirds of the information received at work is transformed into tacit knowledge through the face-to-face interaction such as informal conversations, direct interaction, stories, mentoring, networking, internships and apprenticeships (Nonaka and Takeuchi 1995, Teece 2000, Ivona 2009).

To share tacit knowledge we require extensive personal contact, regular interaction and trust. It is sometimes captured when the knowledge holder joins a network or a community practice (Goffin and Koners 2011). It can only be revealed through practice in a particular context and transmitted through social networks (Schmidt and Hunter 1993).

It is important to create and shape relationships among coworkers and various social networks that assist tacit knowledge exchange among the individuals within a project (Fan and $\mathrm{Ku}$ 2010). There are two processes of sharing tacit knowledge (Bloodgood and Salisbury 2001): i) directly by personal contacts with other employees, and ii) indirectly through information and communication technology (ICT).

The direct interaction of tacit knowledge is performed through the collaborative of knowledge sharing among the members of the organization (Majewska and Szulczyńska 2014).

ICT facilitates sharing of tacit knowledge. For example, it is shared through expert systems, extranets and intranets, e-mail, databases, videoconferences, teleconferences, real or virtual bulletin boards and collaboration software like groupware (Majewska and Szulczyńska 2014). Social networking and online discussion forums can share, critique and validate their collective empirical knowledge easily among individuals and organizations (Laudon and Laudon 2012).

\section{Tacit Knowledge Sharing in Education}

University teachers can improve their teaching skill and researching knowledge by the sharing of tacit knowledge. The reasonability of a university teacher reflects not only the specialization and research but also the teaching and cultivating talents (Semradova and Hubackova 2014). The tacit knowledge is naturally reflected in the process of teaching and researching, is valuable as well as competitive for the university teachers (Venkitachalam and Busch 2012).

Tacit knowledge sharing processes in education are four types as (Yu and Zhou 2015): i) peer review, ii) learning community, iii) thumb-a-lift, and iv) academic conference. 
Peer review: It is a standard practice of tacit knowledge sharing that would encounter teachers when they submit journal articles, case studies, books and apply for sponsorship of scientific foundation or evaluate the quality of teaching, etc. (Singleton 2015).

Learning community: This is formed by a group of teachers who share academic ideas, skills, methods, experience and attitudes through tacit knowledge sharing (Richlin and Cox 2004). The cooperation among teachers with different characters can share properly and motivate creative ideas and solve the problems ( $\mathrm{Yu}$ and $\mathrm{Zhou} \mathrm{2015).}$

Thumb-a-lift: It exists in the tacit knowledge sharing activities of teachers. Academic forum, teaching blogs and discussion space are example of thumb-a-lift (Yu and Zhou 2015).

Academic conference: It is a popular mode of tacit knowledge sharing for teachers (Sumi and Mase 2002). Many teachers prefer to communicate through international or national academic conferences to know other teacher's new views and opinions ( $\mathrm{Yu}$ and Zhou 2015).

\section{Tacit Knowledge Sharing in Construction Industry}

In a construction project, Architecture, Engineering and Construction (AEC) firms rely on their experiences, professional intuition, and other forms of tacit knowledge to complete the work satisfactorily. The experienced workers share their tacit knowledge and experiences with apprentices through a form of storytelling and communities of practice (Brown and Duguid 1991).

\section{Difficulties of Sharing Tacit Knowledge}

The difficulties of sharing tacit knowledge can be related to perception and language, time, value, and distance (Nonaka and Konno 1998).

Perception and language: It is considered as the main difficulties in sharing tacit knowledge. Perception is the characteristic of unconsciousness about a problem for not being aware of the full range of the knowledge. Another difficulty with language lies in the fact that intangible tacit knowledge is held in a non-verbal form (Polanyi 1958).

Time: Time increases challenges for sharing tacit knowledge. The internalization of tacit knowledge requires a long time both for individual and organization, which causes difficulties of sharing tacit knowledge (Bennett and Gabriel 1999).

Value: Value creates difficulties in sharing tacit knowledge. In the globalized world knowledge has become a valuable asset for the development of an organization. But unfortunately many forms of tacit knowledge, such as intuition and rule-of-thumb, have not been considered valuable (Zack 1999).

Distance: At present distance raises difficulties in workplace. The need for face-to-face interaction into more distant is often creates difficulties for sharing of tacit knowledge (Leonard and Sensiper 1998).

\section{Benefits of Sharing Tacit Knowledge}

Sharing of tacit knowledge is beneficial for all organizations. Basis of KM is transfer of individual or collective skill into codified form (Davidavicien and Raudeliunien 2010).

Tacit knowledge sharing provides sustainable competitive advantage to develop tangible assets as an intellectual capital (Leonardi and Treem 2012).

Sharing of tacit knowledge among the employees is beneficial for the organizations. Hence tacit knowledge sharing is vital both for individuals and organizations. 


\section{Barriers of Sharing of Tacit Knowledge}

The capture, transfer and sharing of tacit knowledge is not an easy task (Laudon and Laudon 2012). Sharing of tacit knowledge may cause risks to an individual. For example, for this an individual may loss of competitive advantage over peers or it may provide incomplete or having a questionable track record (Stenmark 2002).

Three key areas that challenge the application and management of tacit knowledge in organizations are identified as: i) the individual, ii) organizational, and iii) technological barriers (Joia and Lemos 2009, Holste and Fields 2010, Laudon and Laudon 2012).

Individual barrier: At the individual level, individual's personality, temperament, attitude, interpersonal skills and pride of ownership by an individual as factors that hindered the management of tacit knowledge. In some cases individuals shy away from sharing their knowledge at the risk of exposing their knowledge (Awad and Ghaziri 2007).

Organizational barrier: Leadership in any organization is worked for the development of processes and strategies in that organization to succeed in the business environment. But leaders in some organizations are barriers to tacit knowledge sharing, because they create bureaucratic and hierarchical organizational structures that are inflexible and hence hinders the transfer of knowledge within the organizations (Joia and Lemos 2009).

Technological barrier: Technology has changed the way organizations operate as it has provided means to instant access to information and data over long distances. But technology does not operate in a vacuum and organizations today are adapting the use of hybrid solutions to facilitate knowledge sharing (Riege 2005).

\section{IMPORTANCE OF TACIT KNOWLEDGE}

From the ancient period it is believed that capital, raw material and labor are the main source for creating and applying knowledge. At present knowledge is considered as an exceptional fund of indescribable economic resources and the dominant source of longterm competitive advantage (Ivona 2009). It is true that knowledge has been of decisive importance in the development of humankind (World Bank 2007). Knowledge is an important asset for countries as it provides potential for economic and social development by providing low cost and effective ways for service provision and production of goods while leading to globalization and competitiveness internationally (World Bank 2012).

Tacit knowledge is important because expertise rests on it and it is a source of competitive advantage as well as being critical to daily management (Nonaka 1994). About $90 \%$ of the knowledge in any organization is embedded and synthesized in tacit form. It plays a key role in influencing the overall effectiveness of knowledge in organizations (Wah 1999).

Due to global economic growth many organizations gave importance of maintaining tacit knowledge sharing environment. The aim of tacit knowledge sharing is to exchange existing personal knowledge in order to create new knowledge (Mongkolajala et al. 2012). The systematic process for acquiring, organizing, sustaining and renewing tacit knowledge of employees has enabled organizations to survive in a robust economy (Mungai 2014).

Tacit knowledge is the main body of organizational knowledge with a priority and is the key to form the individual and organizational innovation capability (Liu and Cui 2012). 
The efficiency of making decisions, production capacity, customer serving and the accuracy of task performance can be improved by the use of tacit knowledge. It increases the smoothness of work and increases the quality of the work (Brockmann and Anthony 1998).

\section{CONCLUSION}

In the study we have discussed the notion of tacit knowledge for achieving organizational goals. We have observed that the attitude toward tacit knowledge sharing has a positive significant for the organizations. Tacit knowledge sharing is important for all organizations and we have stressed on tacit knowledge sharing for the development of the organizations. The organizations should be conscious about the importance of the tacit knowledge of the employee possesses for the development of the organizations.

\section{REFERENCES}

Awad, E.M. and Ghaziri, H. (2007), Knowledge Management, Delhi: Pearson Education.

Beesley, L.G.A. and Cooper, C. (2008), Defining Knowledge Management (KM) Activities: Towards Consensus, Journal of Knowledge Management, 12(3): 48-62.

Bennett, R. H. III and Gabriel, H. (1999), Organizational Factors and Knowledge Management within Large Marketing Departments: An Empirical Study', Journal of Knowledge Management, 3(3): 212225.

Bloodgood, J. and Salisbury, W. (2001), Understanding the Influence of Organizational Change Strategies on Information Technology and Knowledge Management Strategies, Decision Support Systems, 31: 55-69.

Brockmann, E.N. and Anthony, W.P. (1998), The Influence of Tacit Knowledge and Collective Mind on Strategic Planning, Journal of Managerial Issues, 10(2): 204-222.

Brown, J.S. and Duguid, P. (1991), Organizational Learning and Communities-of-Practice: Toward a Unified View of Working, Learning, and Innovation, Organization Science, 2(1): 40-57.

Crowley, B. (2001), Tacit Knowledge, Tacit Ignorance, and the Future of Academic Librarianship, College and Research Libraries, 62(6): 565-584.

Davenport, T.H. and Prusak, L. (2000), Working knowledge: How Organizations Manage What They Know, Boston, Massachusetts: Harvard Business School Press.

Davidavicien, V. and Raudeliunien, J. (2010), ICT in Tacit Knowledge Preservation, $6^{\text {th }}$ International Scientific Conference May 13-14, 2010, Vilnius, Lithuania.

Fan, Yi.-W. and Ku, E. (2010), Customer Focus, Service Process Fit and Customer Relationship Management Profitability: The Effect of Knowledge Sharing, The Service Industries Journal, 30(2): 203-223. Web: http://dx.doi.org/10.1080/02642060802120141

Goffin, K. and Koners, U. (2011), Tacit Knowledge, Lessons Learnt, and New Product Development, Journal of Product Innovation Management, 28 (2): 300-318.

Haldin-Herrgard, T.H. (2000), Difficulties in the Diffusion of Tacit Knowledge in Organizations, Journal of Intellectual Capital, 1(4): 357-365.

Hislop, D. (2009), Knowledge Management in Organizations: A Critical Introduction, $2^{\text {nd }}$ Ed., Oxford University Press, New York.

Holste, J.S. and Fields, D. (2010), Trust and Tacit Knowledge Sharing and Use, Journal of Knowledge Management, 14 (1): 128-140. Web: http:/ /dx.doi.org/10.1108/13673271011015615

Hong, D.; Suh, E. and Koo, C. (2011), Developing Strategies for Overcoming Barriers to Knowledge Sharing Based on Conversational Knowledge Management: A Case Study of A Financial Company, Expert Systems of Applications, 38(12): 14417-14427 Web: http:/ /dx.doi.org/10.1016/j.eswa.2011.04.072 
Ivona, O. (2009), The Importance of Tacit Knowledge Within the Organization: 414-416. Web: http:/ / steconomice.uoradea.ro/anale/volume/2009/v4-management-and-marketing/73.pdf.

Joia, L.A. and Lemos, B. (2010), Relevant Factors for Tacit Knowledge Transfer Within Organizations, Journal of Knowledge Management, 14(3): 410-427.

Laudon, K.C. and Laudon, J.P. (2012), Management Information Systems: Managing the Digital Firm, Harlow, England: Pearson Education Limited.

Leonard, D. and Sensiper, S. (1998), The Role of Tacit Knowledge in Group Innovation, California Management Review, 40(3): 112-132.

Leonardi, P.M. and Treem J.W. (2012), Knowledge Management Technology as a Stage for Strategic Self-Presentation: Implications for Knowledge Sharing in Organizations, Information and Organization, 22(1): 37-59. Web: http://dx.doi.org/10.1016/j.infoandorg.2011.10.003

Liu, Z.-G. and Cui, J. (2012), Improve Technological Innovation Capability of Enterprises Through Tacit Knowledge Sharing, Procedia Engineering, 29: 2072-2076. Web: http:/ / dx.doi.org/10.1016/j.proeng.2012.01.264

Magnier-Watanabe, R.; Benton, C. and Senoo, D. (2011), A Study of Knowledge Management Enablers across Countries, Knowledge Management Research \& Practice, 9: 17-28.

Mahmood, A.; Qureshi, M.A. and Shahbaz, Q. (2011), An Examination of the Quality of Tacit Knowledge Sharing Through the Theory of Reasoned Action, Journal of Quality and Technology Management, VII(I): 39-55.

Majewska, M and Szulczyńska U. (2014), Methods and Practices of Tacit Knowledge Sharing

McAdam, R.; Mason, B. and McCrory, J. (2007), Exploring the Dichotomies Within the Tacit Knowledge Literature: Towards a Process of Tacit Knowing in Organizations, Journal of Knowledge Management, 11(2): 43-59.

Mládková, L. (2012), Sharing Tacit Knowledge within Organizations: Evidence from the Czech Republic, Global Journal of Business Research, 6(2): 105-115. Web: http:/ /dx.doi.org/10.4135/9781446217375

Mongkolajala, H.; Panichpathom, S. and Ngarmyarn, A. (2012), The Development of Tacit Knowledge Sharing behavior among Employees in Organizations, International Journal of Business and Social Research, 2(5): 158-163.

Mungai, G.C.N. (2014), Tacit Knowledge Management in Public Institutions in Kenya: A Case of the Kenya Institute for Public Policy Research and Analysis (Kippra) Nairobi, Master Thesis, University of South Africa.

Nonaka, I. (1991), The Knowledge-Creating Company, Harvard Business Review, 69: 96-104.

Nonaka, I. (1994), A Dynamic Theory of Organizational Knowledge Creation, Organization Science, 5(1): 14-37.

Nonaka, I. and Konno, N. (1998), The Concept of 'Ba': Building a Foundation for Knowledge Creation, California Management Review, 40(3): 40-54.

Nonaka, I. and Nishiguchi, T. (2001), Knowledge Emergence: Social, Technical, and Evolutionary Dimensions of Knowledge Creation, Oxford University Press, New York, NY.

Nonaka, I. and Takeuchi, H. (1995), The Knowledge-Creating Company: How Japanese Companies Create the Dynamics of Innovation, Oxford University Press, New York, NY.

Pavlicek, A. (2009), The Challenges of Tacit Knowledge Sharing in a Wiki System, Proceedings from the IDIMT Conference 2009: 391-397.

Phelps, C.; Heidl, R. and Wadhwa, A. (2012), Knowledge, Networks, and Knowledge Networks: A Review and Research Agenda, Journal of Management, 38(4): 1115-1166.

Polanyi, M. (1958), Personal knowledge, Towards a Post-critical Philosophy (Reprinted 2002), London: Routledge, Taylor and Francis Group. 
Polanyi, M. (1966), The Tacit Dimension, Peter Smith, Gloucester, MA, University of Chicago Press: Chicago.

Richlin, L. and Cox, M.D. (2004), Building Faculty Learning Communities, Jossey-Bass, San Francisco.

Riege, A. (2005), Three-Dozen Knowledge-Sharing Barriers Managers Must Consider, Journal of Knowledge Management, 9(3):18-35.

Schmidt, F.L. and Hunter, J.E. (1993), Tacit Knowledge, Practical Intelligence, General Mental Ability, and Job Knowledge, Current Directions in Psychological Science, 2: 8-9.

Semradova, I. and Hubackova, S. (2014), Responsibilities and Competences of a University Teacher, Procedia-Social and Behavioral Sciences, 159: 437-441. Web: http://dx.doi.org/10.1016/j.sbspro.2014.12.403

Singleton, B. (2015), Peer Review, Contemporary Theatre Review, 25(1): 26-29. Web: http:/ /dx.doi.org/10.5935/0004-2749.20150001

Stenmark, D. (2002), Sharing Tacit Knowledge: A Case Study at Volvo, In S. Barnes (Ed.), Knowledge Management Systems: Theory and Practice, Thomson Learning, London.

Sumi, Y. and Mase, K. (2002), Conference Assistant System for Supporting Knowledge Sharing in Academic Communities, Interacting with Computers, 14(6): 713-737. Web: http:/ /dx.doi.org/10.1016/S0953-5438(02)00018-8

Suppiah, V. and Sandhu, M.S. (2010), Organizational Culture's Influence on Tacit KnowledgeSharing Behavior, Journal of knowledge management,15(3): 462-477.

Takeuchi, H. and Nonaka, I. (2004), Hitotsubashi on Knowledge Management, John Wiley, Singapore.

Teece, D.J. (2000), Managing Intellectual Capital: Organizational, Strategic, and Policy Dimensions, Oxford University Press, New York, NY.

Venkitachalam, K. and Busch, P. (2012), Tacit Knowledge: Review and Possible Research Directions, Journal of Knowledge Management, 16(2): 365-371. Web: http:/ / dx.doi.org/10.1108/13673271211218915

Wah, L. (1999), Making Knowledge Stick, Management Review, 88(5): 24-33.

Within an Enterprise: an Empirical Investigation, Oeconomia Copernicana, 5(2): 35-48, http://dx.doi.org/10.12775/OeC.2014.012

World Bank (2007), Building Knowledge Economies: Advanced Strategies for Development, Washington DC: World Bank.

World Bank (2012), Knowledge for Development Program (K4D). Web: http://go.worldbank.org/8DG6O1F0I0

$\mathrm{Yu}$, D. and Zhou, D. (2015), Tacit Knowledge Sharing Modes of University Teachers from the Perspectives of Psychological Risk and Value, International Journal of Higher Education, 4(2): 214224. Web: http://dx.doi.org/10.5430/ijhe.v4n2p214

Zack, M.H. (1999), Managing Codified Knowledge, Sloan Management Review, 40(4): 45-58. 